\title{
Penggunaan Mobile Learning dengan Live Streaming Facebook pada Mata Pelajaran Qur'an Hadith
}

\author{
${ }^{1}$ Husniyatus Salamah Zainiyati; ${ }^{2}$ Nailul Muna \\ 1 \& 2 UIN Sunan Ampel Surabaya, Indonesia \\ ${ }^{1}$ husniyatussalamah@uinsby.ac.id; ${ }^{2}$ gapaiiharapan@gmail.com
}

\begin{abstract}
This study aims to identify the use of Mobile Learning by using Facebook Live Streaming in the student learning process at MTs Robithotul Ashfiya' Sidokumpul Bungah Gresik for Qur'an Hadith subjects. This is motivated by the activities of the Qur'an Hadith teacher at MTs Robithotul Ashfiya, who are busy outside the madrasa, so most of the teaching and learning process uses bold methods. This study involved students in grades 7 (seven) in grading 9 (nine) and 1 (one) education staff at MTs Robithotul Ashfiya as Madrasah Operators. The research uses an exploratory case study method. The research approach uses qualitative methods to obtain accurate information about the effectiveness of using mobile learning with Facebook live streaming on Qur'an Hadith subjects at Madrasah Tsanawiyah Robithotul Ashfiya' Sidokumpul Bungah Gresik. The results of this study explain that the use of mobile learning with Facebook live streaming on Qur'an Hadith subjects at the Madrasah Tsanawiyah unit level runs effectively.
\end{abstract}

Keywords. Mobile Learning; Facebook Live Streaming; Qur'an Hadith.

\begin{abstract}
Abstrak. Penelitian ini bertujuan untuk mengidentifikasi penggunaan Mobile Learning dengan menggunakan Live Streaming Facebook pada proses pembelajaran siswa di MTs Robithotul Ashfiya' Sidokumpul Bungah Gresik mata pelajaran Qur'an Hadith. Hal ini dilatarbelakangi oleh kegiatan Guru Qur'an Hadith di MTs Robithotul Ashfiya' yang memiliki kesibukan di luar madrasah, sehingga sebagian proses belajar mengajarnya menggunakan metode daring. Penelitian ini melibatkan siswa siswi kelas 7 (tujuh) sampai dengan kelas 9 (sembilan) dan 1(satu) orang Tenaga Kependidikan MTs Robithotul Ashfiya' sebagai Operator Madrasah. Penelitian menggunakan metode studi kasus eksplorasi dan pendekatan penelitiannya menggunakan metode kualitatif yang digunakan untuk mendapatkan informasi yang akurat mengenai efektifitas hasil dari penggunaan mobile learning dengan live streaming Facebook pada mata pelajaran Qur'an Hadith di Madrasah Tsanawiyyah Robithotul Ashfiya' Sidokumpul Bungah Gresik. Hasil penelitian ini menjelaskan bahwa penggunanan mobile learning dengan live streaming facebook pada mata pelajaran Qur'an Hadith di tingkat satuan Madrasah Tsanawiyyah berjalan dengan efektif.
\end{abstract}

Kata kunci. Mobile Learning; Live Streaming Facebook; Qur'an Hadith. 


\section{A. PENDAHULUAN}

Era modern ini handphone merupakan media komunikasi yang sudah banyak digunakan oleh seluruh jenjang usia. Bahkan handphone juga sudah merambah masuk ke pelosok desa. Hampir bisa dikatakan tidak ada yang tidak mengetahui penggunaan handphone di era sekarang. Sering pada beberapa provider perangkat keras tersebut yang memberikan fitur bawaan berupa media-media sosial, utamanya facebook. Sebagaimana yang dirilis oleh Trans Media dan CNBC pada Tahun 2019 Facebook sudah diakses lebih dari 2,38 miliar user di seluruh dunia.

Peningkatan pengguna dari Tahun 2018 yang berjumlah 2,2 miliar User ini menunjukkan bahwa minat penggunaan Media Sosial dari tahun ke tahun semakin meningkat, seiring meningkatnya pengguna handphone. Karena fitur bawaan yang diberikan oleh provider handphone ini tadi yang memicu penggunaan Media Sosial sebagai sarana memperoleh segala macam informasi yang berkembang.

Dalam perjalanannya, Facebook terus meningkatkan kualitasnya dalam menarik minat para User agar mereka semakin tertarik menggunakan Media Sosial tersebut. Salah satu upaya Facebook adalah dengan memberikan fitur Live Streaming dimana para User dapat menyiarkan langsung kegiatannya melalui platform tersebut.

Awal kemunculan platform Live Streaming masih terbatas video yang menyiarkan aktivitas User secara langsung namun hasilnya tidak bisa didownload serta menggunakan durasi waktu yang pendek. Namun memasuki tahun 2020 platform live streaming dikembangkan dengan fitur download setelah selesai siaran langsung. Seiring berkembangnya zaman, fitur live streaming ini semakin mudah diakses karena sudah tersedia juga mobile version. Dimana versi ini sangat membantu User untuk menyiarkannya dimanapun dan kapanpun cukup dengan akses internet serta paket data yang cukup.

Penggunaan Handphone sudah menjadi hal lumrah di era modern ini. Begitu pula bagi sebagian besar siswa-siswi MTs Robithotul Ashfiya' Sidokumpul Bungah Gresik. Beberapa materi pelajaran sering menggunakan Handphone sebagai media pembelajaran, termasuk materi Qur'an Hadith. Qur'an hadith merupakan salah satu cabang mata pelajaran Pendidikan Agama Islam yang focus dalam memahami dan menelaah hal-hal yang berkaitan dengan sumber utama hukum Islam yaitu al-Qur'an dan al-Hadith.

Tujuan dari mempelajarinya adalah agar peserta didik mampu membaca al-Qur'an dengan baik dan benar serta mengetahui kaidah-kaidah dan makna ayat-ayat al-Qur'an tersebut. Begitu pula peserta didik diharapkan dapat memmahami hadith-hadith pilihan yang ada pada materi Qur'an Hadith. Bukan hanya memahami namun juga hafal, sehingga peserta didik dapat menjalankan kehidupan ini sebagaimana yang telah dicontohkan pada Hadith Nabi Muhammad SAW.

Roy Killen (2007) berpendapat bahwa pendekatan yang dapat dilakukan dalam kegiatan pembelajaran itu ada dua macam (a) pendekatan yang menjadikan guru sebagai pusat kegiatan (teacher-centred approaches). Pada pendekatan ini guru menjadi komponen paling penting dan menentukan dalam mengimplementasikan strategi pembelajaran. Dominasi peran seorang guru sangat dibutuhkan pada pendekatan ini, maksudnya materi dapat dikuasai oleh peserta didik bilamana guru dapat menyampaikan materi dengan baik dan terstruktur pada tiap tahapan kegiatan. Kegiatan ini utamanya terfokus pada kemampuan akademik peserta didik; (b) Pendekatan dimana pusat kegiatannya adalah peserta didik (student-centred approaches), pendekatan ini memahami bahwa tiap peserta didik memiliki kemampuan berbeda dalam memahami setiap materi pelajaran yang disampaikan begitu juga dalam mengikuti setiap kegiatan pembelajaran. Perbedaan itu adakalanya dalam hal kemampuan, kesenangan, minat, pengalaman dan bisa jadi karena metode belajar yang berbeda antara satu dan yang lainnya. 
Husniyatus Salamah Zainiyati; Nailul Muna: Penggunaan Mobile Learning...

Pembelajaran Qur'an Hadith di Madrasah Tsanawiyyah Robithotul Ashfiya' Sidokumpul Bungah Gresik berorientasi pada kemampuan peserta didik dalam meningkatkan mutu bacaannya. Peningkatan mutu bacaan peserta didik perlu dijaga dan atau ditingkatkan mengingat sebagian peserta didik sudah menyelesaikan pembelajaran alQur'an pada lembaga-lembaga semacam Tamaan Pendidikan al-Qur'an pada saat mereka berada di jenjang Madrasah Ibtidaiyyah. Meskipun begitu sebagian siswa-siswi Madrasah Tsanawiyyah Robithotul Ashfiya' mengalami kendala dalam memahami bacaan al-Qur'an. Hal ini dibuktikan dari hasil wawancara dengan beberapa peserta didik dan menghasilkan bahwa 30\% diantara mereka masih belum bisa membaca al-Qur'an sesuai kaidah yang ada.

Pembelajaran Qur'an Hadith juga berorientasi pada kemampuan peserta didik dalam menghafalkan beberapa hadith pilihan. Bukan hanya menghafalkan namun juga besar harapan mereka dapat menerapkannya dalam kesehariannya. Juga peserta didik nantinya dapat mengetahui istilah-istilah yang ada kaitannya dengan al-Qur'an dan alHadith. Peserta didik pada kelas Madrasah Tsanawiyyah sudah memasuki jenjang remaja dimana pada usia ini dimulainya seseorang untuk berfikir logis, abstrak serta realistis dalam menghadapi kehidupannya (Mc Devitt et al., 2010).

Pemaparan materi yang menarik dan kekinian sangat digemari pada usia ini. Dalam hal itulah penggunaan metode mobile learning lebih mudah dilakukan. Dimana banyak dari mereka sudah bisa mengoperasikan hadphone dengan baik. Dalam hal ini kemudian Guru membemberikan tugas melalui handphone baik berupa video, maupun lembar-lembar tugas, bahkan juga menggunakan live streaming kemudian siswa-siswi memberikan umpan balik berupa review dan lembar kerja. Hal ini juga mempertimbangkan beberapa Guru Pengampu mata pelajaran yang juga memiliki kesibukan di luar lembaga. Sehingga diterapkanlah metode ini untuk para siswa.

\section{B. METODE}

Penelitian ini menggunakan metode penelitian kualitatif sebagai instrumen kunci, pengambilan sampel sumber data dilakukan secara purposive dan snowball, teknik pengumpulan dengan triangulasi (gabungan), analisis data bersifat induktif atau kualitatif, dan hasil penelitian kualitatif lebih menekankan makna daripada generalisasi. Peneliti menggunakan metode penelitian kualitatif sebagai suatu pendekatan atau penelusuran untuk mengeksplorasi dan memahami suatu gejala sentral. Peneliti mewawancarai peserta penelitian atau partisipan dengan mengajukan pertanyaan yang umum dan agak luas untuk mengerti gejala sentral tersebut, Informasi kemudian dikumpulkan yang berupa kata maupun teks. Kumpulan informasi tersebut kemudian dianalisis. Hasil analisis peneliti dijabarkan dengan penelitian-penelitian ilmuwan lain yang dibuat sebelumnya. Hasil akhir penelitian kualitatif dituangkan dalam bentuk laporan tertulis (Creswell \& Creswell, 2018; Sugiyono, 2010).

\section{HASIL DAN PEMBAHASAN}

\section{Mobile Learning}

Clark Quinn memberikan pendapatnya bahwa mobile learning didefinisikan sebagai "The intersection of mobile computing and e-learning: accessible resources wherever you are, strong search capabilities, rich interaction, powerful support for effective learning, and performance-based assessment. E- Learning independent of location in time or space." (Wijaya, 2007). Mobile learning merupakan model pembelajaran yang memanfaatkan TIK. Mobile learning menyajikan materi pembelajaran yang bisa diakses peserta didik pada setiap saat dan diberikan sajian visualisasi materi yang menarik.

Mobile learning (m-learning) dapat diartikan juga sebagai model pembelajaran dengan menggunakan seluler sebagai media pembelajaran. Pada model ini juga dapat 
berupa smart phone, PDA (Portabel Digital Asisten), tablet PC, iPod dan sejenisnya. Sedangkan Aplikasi Mobile adalah aplikasi yang secara khusus dirancang untuk platform Mobile misalnya Android, iOS atau Windows Mobile Aplikasi Mobile juga di kenal sebagai web app, online app, iPhone app atau smartphone app (Pressman, 2005).

Konsep long live education dapat terpenuhi dengan menggunakan model pembelajaran mobile learning, hal ini dikarenakan model pembelajarannya yang dapat dilakukan serta diakses di manapun berada dan kapanpun dikehendaki tanpa harus menentukan terlebih dahulu tempat dan waktu yang diinginkan. Sehingga pengguna bisa mengakses konten pendidikan tanpa terikat ruang dan waktu (Muyaroah, 2017). Simamora (2020) menggambarkan di mana m-Learning adalah suatu konsep belajar yang menggunakan teknologi informasi dan telekomunikasi.

Metode transfer materi pembelajaran yang tidak jarang diiringi dengan visualisasi dan desain menarik, dilengkapi dengan audio-video, maupun virtual-reality nampaknya sesuai dengan minat siswa. Fitur lain yang memungkinkan siswa berinteraksi dengan teman lainnya bisa melalui pengiriman pesan singkat, chatting, maupun bergabung dalam forum diskusi yang tersedia.

Bagi para pengajar, ketersediaan berbagai aplikasi yang menggunakan manfaat dari ICT literacy juga memberikan kemudahan pengajar dalam memberikan materi tambahan yang dapat mendukung proses belajar mengajar siswa.

Konsep mobile learning pada jenjang Pendidikan Menengah sebaiknya memiliki arah pemikiran sebagaimana berikut (Robinson \& Wizer, 2016):

a. Konsep M-learning lebih fokus pada kelas pembelajaran maya yang memungkinkan interaksi antaraguru dan siswa. Interaksi tersebut sebagaimana penyediaan materi ajar, ruang discuss, penyampaian tugas dan pengumuman penilaian.

b. Teknologi yang diadopsi sebaiknya efektif secara pedagogig dan dinilai sebagai sebuah sebuahpembaharuan. Selain itu teknologi yang dipilih sebaiknya memberikan kemudahan ketika pengguna mengakses meskipun tersedia dengan distrubusi yang merata di lingkungan siswa maupun guru.

Pemikiran di atas menjadi lebih baik lagi mempertimbangkan potensi pengembangan yang ada pada m-learning. Diantara potensi tersebut adalah:

a. Hemat tempat. Metode m-learning dapat dilakukan dimanapun selama ketersediaan handphone mendukung, tanpa menyediakan tempat khusus.

b. Dapat dilakukan tanpa ada batasan waktu tertentu.

c. Portabilitas. Dengan fitur yang sangat beragam, maka m-learning menyediakan banyak sajian metode yang dapat dioperasikan oleh siapapun dan dengan tipe perangkat apapun.

d. Konektifitas. Dengan kemampuan menyerap akses internet maka m-learning dapat menggunakan banyak cara seperti email, facebook, whatsapp, youtube, dan aplikasi lainnya dalam melakukan proses belajar mengajar.

e. Instan. Aplikasi-aplikasi yang ada pada handphone (HP) sifatnya mudah digunakan tanpa harus booting seperti yang ada pada computer. Ini akan memudahkan seseorang dalam mengoperasikan aplikasi apapun.

f. Kelengkapan fungsi. Dengan HP seseorang bisa melakukan banyak hal. Sebagai contoh kecil adalah ketersediaan kalkulator, kalender, kompas, prakiraan cuaca, editing foto, editing video dan lain sebagainya dapat dilakukan cukup dengan satu HP. 
Husniyatus Salamah Zainiyati; Nailul Muna: Penggunaan Mobile Learning...

g. Group atau teamwork. Dengan HP peserta didik dapat berinteraksi antara satu dan lainnya dengan lebih efektif dan tanpa batasan tempat dan waktu.

Dengan potensi-potensi yang dimiliki oleh m-learning tersebut memberikan peluang kemungkinan untuk mengembangkan kreatifitas, efektifitas dan produktifitas yang ada pada masing-masing pengguna.

Namun demikian dalam penggunaannya, m-learning juga perlu mempertimbangkan beberapa hal: 1) Harga; 2) Biaya konektivitas; 3) Keterbatasan keyboard; 4) Kecilnya ukuran layar; 5) Perbedaan fitur bawaan pada tiap-tiap tipe dan merk HP; dan lain sebagainya.

\section{Media Pembelajaran}

"Media" adalah sebuah kata yang berasal dari Bahasa Latin, yaitu medius dan secara etimologi berarti sebagai bahan, alat atau teknik. Dari pengertian secara harfiah ini kemudian berkembang kepada pengertian secara ilmiah, yaitu bahan atau alat yang digunakan dalam kegiatan belajar mengajar dengan tujuan agar proses transformasi ilmu antara Guru dan Peserta Didik dapat berjalan tepat guna dan sesuai daya guna (Jhon, n.d.). Dengan demikian dapat diartikan bahwa dengan pemanfaatan bahan ajar yang tepat maka akan mempermudah seorang Pendidik untuk menyampaikan materi kepada Peserta Didik. Dan begitu pula Peserta Didik akan lebih mudah menyerap materi yang disampaikan jika media, bahan dan alat pembelajarannya tepat guna.

Pendidik yang tidak bisa mempergunakan media pembelajaran dengan tepat maka proses pembelajaran menjadi kurang efektif. Sehingga media pembelajaran memiliki peran aktif yang besar dalam proses pembelajaran. Mengemas media pembelajaran dengan menarik juga akan menjadikan keinginan peserta didik dalam mempelajari materi lebih meningkat serta menumbuhkan semangat belajar mereka. Sehingga besar kemungkinan peserta didik akan mampu menyerap dan menangkap seluruh materi.

Kelas yang baik adalah kelas yang memiliki rasa keingintahuan yang tinggi. Dan dengan menggunakan media pembelajaran yang kekinian dan up to date maka kelas akan jadi semakin terasa hidup karena pada diri mereka akan banyak timbul pertanyaanpertanyaan baru. Ketertarikan pada materi yang disampaikan inilah yang menjadi kunci utama seseorang dapat menyerap segala sesuatu dengan baik, terutama bagi peserta didik pada usia remaja. Rasa ingin tahu yang tinggi menyebabkan mereka juga ingin mencoba hal-hal baru yang menarik bagi mereka.

Penggunaan handphone dan laptop atau media elektronik lain sebagai media pembelajaran juga bisa menjadi salah satu solusi untuk menarik minat belajar peserta didik. Sebagai contoh pada mata pelajaran Qur'an Hadith di mana mata pelajaran ini sering kurang diminati oleh peserta didik. Maka moderasi sistem dan metode pembelajaran menjadi salah satu tawaran solusi yang tepat untuk menarik perhatian serta minat belajar siswa terhadap mata pelajaran tersebut.

Lebih spesifik jika media pembelajaran tersebut juga ditunjang dengan kemajuan informasi dan teknologi. Seperti penggunaan media sosial (medsos) dalam menyampaikan materi. Ketertarikan generasi millennial pada media sosial sudah sangat besar sekali. Sehingga kolaborasi yang tepat antara penggunaan m-learning dengan pemilihan media sosial akan menawarkan solusi keminatan generasi millennial pada materi pembelajaran.

Sebagai contoh pembelajaran hadith secara online pada kelas 8 MTs Robithotul Ashfiya' Sidokumpul Bungah Gresik yang dilanjutkan dengan review hasil pembelajaran melalui media facebook live streaming menunjukkan peningkatan pemahaman hadith. Hal ini dibuktikan ketika sesi tanya jawab banyak dari siswa-siswi kelas 8 di MTs Robithotul Ashfiya' yang menjawab dengan baik dan tepat. 


\section{Live Streaming Facebook}

Facebook adalah sebuah layanan jejaring sosial yang diluncurkan pada bulan Februari 2004, dimiliki dan dioperasikan oleh Facebook, Inc. Sebagaimana dikutip dari laman http://id.wikipedia.org/wiki/Facebook dinyatakan bahwa Pendiri Facebook (FB) adalah Mark Zuckerberg kemudia mengembangkannya bersama sesama mahasiswa Universitas Harvard sekaligus kawan-kawan sekamarnya, Chris Hughes, Dustin Moskovitz, Andrew Mc Collum, dan Eduardo Saverin ("Meta Platforms," 2021).

Pada awal kemunculannya FB bernama Face Mash yang kemudian pada tahun 2003 mulai dikembangkan oleh Mark Zuckerberg menjadi Facebook dan itupun masih berupa direktori data siswa di Harvard dengan mencantumkan foto dan biodata singkat pengguna. Dikarenakan saat itu tidak ada data Base Online, maka Zuckerberg mendapatkan ancaman sebagai penerobos keamanan data Harvard. Karena hal itulah dia dikeluarkan dari Harvard University yang justru dikeluarkannya dia dari universitas membuat dia berfikir untuk menjadikan Facebook sebagai hak cipta paten miliknya ("Meta Platforms," 2021).

Hasil pengembangan Facebook yang pada awal peluncurannya pada tahun 2004 dengan nama perusahaan The Facebook masih berupa penyampaian ide-ide dan gagasan pemikiran yang ditulis pada jejaring sosial terbatas hanya pada sesama teman di Universitas Harvard. Dan terbukti 50\% Mahasiswa bergabung di laman sosial ini. Selanjutnya dia bekerja sama dengan pendiri Paypal, Peter Thiel untuk mengembangkan The Facebook dengan jangkauan lebih luas. Ternyata banyak yang menyambut positif atas kemunculannya ("Meta Platforms," 2021).

Maka Mark Zuckerberg mengembangkan lebih jauh lagi dengan menambah fiturfitur yang ada, sehingga dengan menggunakan satu fasilitas saja sudah didapatkan banyak sekali fungsi. Diantaranya adalah media chatting, berbagi foto, berbagi video, berbagi gagasan, cerita dan pemikiran-pemikiran, penggunaan video meet, call streaming, dan conference bahkan juga disediakan fitur facebook business bagi mereka yang menginginkan pendapatan tambahan dengan menggunakan FB. Ada juga fasilitas pengiklanan menggunakan FB dan juga siaran langsung atau live streaming ("Meta Platforms," 2021).

Karena dianggap lengkap inilah kemudian semenjak kemunculannya hingga akhir tahun 2019 FB memiliki user yang paling tinggi diantara para pengguna social media lainnya (Kemp, 2019):

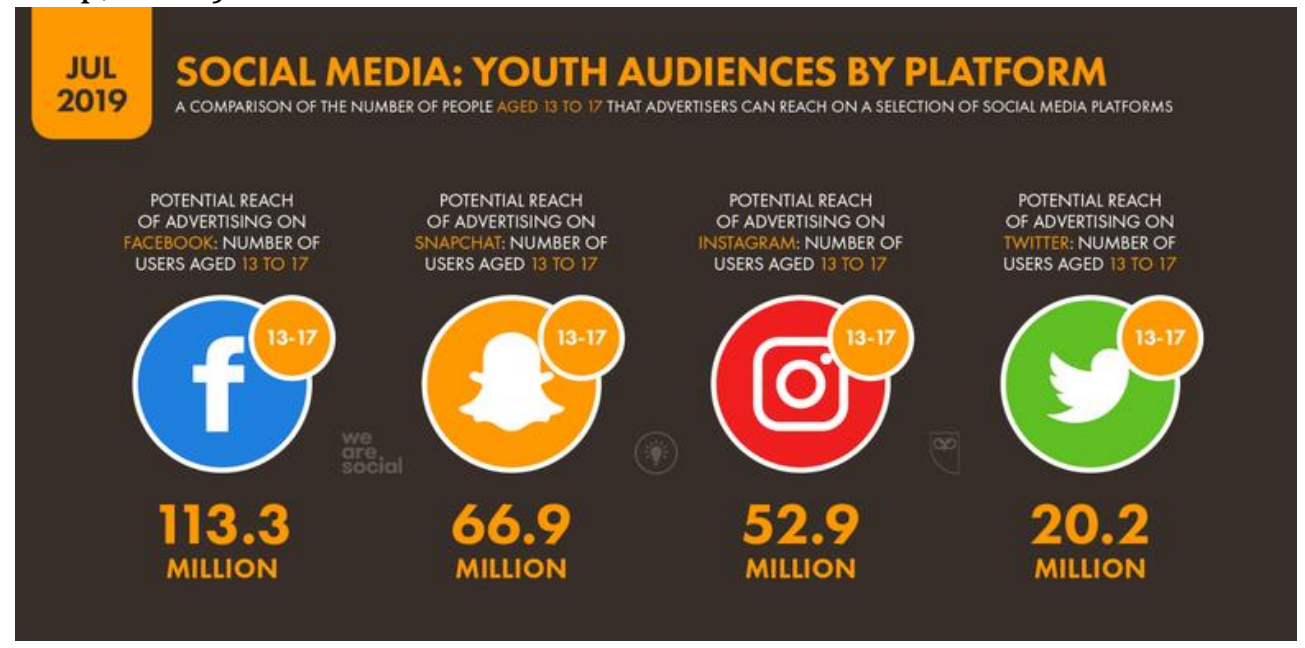

Gambar 1. Pengguna Sosial Media

Disebabkan karena Popularitasnya yang mendunia dan menjadi salah satu jejaring sosial paling populer inilah kemudian FB mengembangkan terus fitur yang ada. Facebook memungkinkan penggunanya membuat profil diri, memutakhirkan profilnya dengan 
Husniyatus Salamah Zainiyati; Nailul Muna: Penggunaan Mobile Learning...

informasi pribadi, misalnya alamat rumah, nomor ponsel, hobby, dan pandangan keagamaan. Menurut Petrovic et al., (2012) selain membuat profil diri, pengguna facebook juga bisa mendaftarkan pengguna lain sebagai teman sehingga bisa saling kirim pesan, bergabung dalam grup atau kelompok tertentu, mengirimkan dan/atau menandai gambar, serta meninggalkan komentar terhadap gambar yang sudah dikirim oleh pengguna lain (Brook et al., 2013).

Perjalanan FB menjadi lebih lengkap dengan ditambahnya fitur Facebook Live. Maksudnya adalah sebuah fitur dari Facebook untuk melakukan siaran langsung dengan kamera saku. Fungsi Facebook Live memungkinkan pengguna Facebook untuk berinteraksi secara langsung dengan pengguna lain.

Demi menunjang kebutuhan pengguna dan menarik minat pengguna untuk mau menggunakan Facebook Live, pihak Facebook meluncurkan fitur-fitur baru seperti siaran langsung yang diperuntukkan bagi pengguna tertentu, yang mana hal ini memungkinkan pengguna melakukan siaran dengan jangkauan audiensi orangorang yang dipilih pengguna misalnya saja grup tertentu. Selain itu pengguna juga bisa melakukan siaran yang diberlakukan dengan judul sebuah event, jadi hanya pengguna yang melakukan booking atau reservasi saja yang bisa menyaksikan live streamingnya.

Patria dan Yulianto (2011) berpendapat bahwa interaksi (diskusi) pada FB dapat dilakukan dengan cara-cara berikut:

a. Asynchronous yaitu di saat Guru dan peserta didik tidak berada dalam waktu yang bersamaan; misalnya melalui fitur message dan melalui fitur comment.

b. Synchronous yakni disaat Guru dan peserta didik berada dalam waktu yang bersamaan. Interaksi ini dilakukan melalui fitur chatting yang ada pada facebook. Dengan demikian, baik guru maupun siswa mereka dengan mudah berdiskusi maupun bertukar informasi.

Dari sini kemudian diketahui bahwa di FB ada beberapa fitur yang dapat digunakan sebagai sarana pembelajaran (Madcoms, 2009). Fitur-fitur tersebut adalah:

a. Facebook Groups. Dengan memanfaatkan fitur ini seseorang dapat membuat kelompokkelompok diskusi tertentu baik secara terbuka maupun tertutup (tebatas dan hanya bisa dinikmati oleh user yang terdaftar pada grup tersebut saja)

b. Facebook Share. Fiitur ini adalah dengan men-share (membagikan) materi baik berupa tulisan, foto, maupun video kepada teman diskusi.

c. Facebook Chat. Fitur ini digunakan untuk mengobrol secara langsung dan melakukan diskusi secara sistem online secara langsung.

d. Facebook Note. Fitur ini juga dapat digunakan dengan membuat tulisan-tulisan sebagai bahan materi diskusi.

e. Facebook Quiz. Fitur ini bisa digunakan sebagai media evaluasi pembelajaran atau ujian onlineyang interaktif untuk peserta didik.

f. Facebook Live. Dengan menggunakan fitur yang menyatu bersama facebook status ini seorang user dapat melakukan live streaming atau broadcasting secara langsung baik menggunakan HP maupun dengan laptop.

Pada facebook live inilah yang akan menjadi media dalam pembelajaran. Karena facebook live menyajikan pembelajaran secara audio visual dan dapat dilakukan baik secara asynchronous maupun synchronous. 


\section{Live Streaming Facebook pada Mata Pelajaran Qur'an Hadith}

Long live education (belajar sepanjang masa) menjadi jargon metode pembelajaran online, dimana pembelajaran dapat dilakukan dimanapun, kapanpun dan pada materi pelajaran apapun. Pemilihan media pembelajaran yang tepat dan sesuai oleh pendidik dapat menambah efektifitas proses pembelajaran, begitu juga pemilihan media pembelajaran yang menarik dapat menimbulkan rasa ingin tahu yang tinggi pada peserta didik, mempermudah terjadinya proses pembelajaran tersebut, dan dapat menjadikan peserta didik lebih aktif dalam proses pembelajaran. Dengan tepat guna media pembelajaran juga dapat terjalin komunikasi antara pendidik dan peserta didik (Arifin, 2018).

Pada beberapa materi dan bab materi pelajaran Qur'an Hadith, Guru pengampu mata pelajaran tersebut menggunakan live streaming facebook dalam menyampaikan materinya. Utamanya pada masa pandemi covid-19 yang terjadi mulai akhir tahun 2019 dan mewabah di Indonesia pada awal tahun 2020 (Bulan \& Zainiyati, 2020)

Selama Guru menjelaskan secara live, peserta didik mengisi kolom komentar sebagai bukti kehadiran. Kemudian setelah seleai penyampaian materi dibuka sesi tanya jawab pada kolom komentar. Setelah berakhir, peserta didik diminta untuk membuat review dari materi yang disampaikan.

Kendala yang dihadapi pada live streaming di MTs Robithotul Ashfiya' Sidokumpul Bungah Gresik adalah seringnya kurang fokus antara komentar dengan materi yang disampaikan. Hal ini dikarenakan belum adanya filtrasi dalam kolom komentar. Kelebihan dari live streaming ini pengguna juga dapat mengetahui siapa yang melihat saat itu dan berapa durasi yang dilakukan pada masing-masing viewer. Siaran langsung yang dilakukan juga untuk kemudian dapat dipromosikan kepada seluruh pengguna facebook baik yang mengikuti atau tidak. Sehingga dapat dijadikan sebagai media iklan untuk mengenalkan pemilik laman atau produk yang dimiliki.

\section{KESIMPULAN}

Dalam pembahasan dan penelitian ini dapat disimpulkan beberapa hal. Diantaranya adalah Model pembelajaran dengan menggunakan media elektronika sebagaimana model m-learning dan e-learning bisa dijadikan inovasi dalam proses pembelajaran. Pemilihan media pembelajaran yang tepat akan memberikan banyak hal positif baik bagi Guru maupun peserta didik. Live streaming facebook bisa dijadikan media dalam menyampaikan materi pembelajaran baik di dalam kelas maupun di luar kelas. Kelebihan dan kekurangan yang ada pada proses live streaming tidak menjadi kendala utama dalam penggunaannya sebagai media pembelajaran Pembelajaran online di MTs Robithotul Ashfiya' utamanya pada mata pelajaran Qur'an Hadith dapat membawa peserta didik untuk mewujudkan long live education (pembelajaran sepanjang masa). Pengembangan tekhnologi dan informasi yang tepat guna menjadikan peserta didik lebih kreatif dan termotivasi untuk melakukan inovasi-inovasi dalam menyimpulkan serta menerima materi yang disampaikan.

Dari kesimpulan di atas maka seorang pendidik harus sudah melek tekhnologi dan informasi serta dapat mengoperasikan dengan baik tekhnologi dan informasi tersebut. Karena tidak bisa dipungkiri bahwa kemajuan arus tekhnologi dan informatika berjalan dengan sangat cepat. Media pembelajaran facebook bukan lagi mengacu pada guru sebagai pusat pembelajaran, namun peserta didik yang menjadi pusat. Melalui facebook para siswa dapat merekonstruksi pengetahuannya sendiri dengan cara belajar mandiri melalui dunia internet. Dalam hal ini, guru hanya sebagai fasilitator dan evaluator.

Dengan media pembelajaran facebook, peserta didik dilatih untuk terus belajar mandiri, bertanggung jawab, aktif, bekerja sama dan berkolaborasi dengan orang lain dalam menyelesaikan permasalahan, mengembangkan strategi belajar, dan juga melatih peserta didik untuk menguasai Tekhnologi, Informasi dan Komputerisasi. 
Husniyatus Salamah Zainiyati; Nailul Muna: Penggunaan Mobile Learning...

\section{DAFTAR PUSTAKA}

Arifin, Z. (2018). Meningkatkan hasil belajar dengan strategi pembelajaran peningkatan kemampuan berpikir. Jurnal THEOREMS (The Original Research of Mathematics), 2(2), 42.

Brook, A., Lynch, S., \& Debono, M. (2013). Using standards rubrics to assure gBrook, A., Lynch, S., \& Debono, M. (2013). Using standards rubrics to assure graduate capabilities within the context of undergraduate liberal arts programmes. Journal of Teaching and Learning for Graduate Employability,. Journal of Teaching and Learning for Graduate Employability, 4(1), 23-38. https://doi.org/10.21153/jtlge2013vol4no1art559

Bulan, S., \& Zainiyati, H. S. (2020). Pembelajaran Online Berbasis Media Google Formulir dalam Tanggap Work From Home Masa Pandemi Covid-19 di Madrasah Ibtidaiyah Negeri (MIN) 1 Paser. SYAMIL: Jurnal Pendidikan Agama Islam (Journal of Islamic Education), 8(1), 15-34. https://doi.org/10.21093/sy.v8i1.2300

Creswell, J. W., \& Creswell, J. D. (2018). Research design: Qualitative, quantitative, and mixed methods approaches (Fifth edition). SAGE.

Jhon, D. (n.d.). Latuheru. 1998. Media Pembelajaran Dalam Proses Belajar Mengajar Masa Kini.

Kemp, S. (2019, July 23). Number of social media users passes 3.5 billion. We Are Social Singapore. https://wearesocial.com/sg/blog/2019/07/number-of-social-media-users-passes-3-5billion/

Killen, R. (2007). Teaching strategies for outcomes-based education. Juta and Company Ltd.

Madcoms, M. (2009). Trik Rahasia Mengoptimalkan Facebook. Andi.

Mc Devitt, T. M., Ormrod, J. E., Cupit, G., Chandler, M., \& Aloa, V. (2010). Child Development and Education. Merrill Upper Saddle River, NJ.

Meta Platforms. (2021). In Wikipedia bahasa Indonesia, ensiklopedia bebas. https://id.wikipedia.org/w/index.php?title=Meta_Platforms\&oldid=19600771

Muyaroah, S. (2017). Efektifitas Mobile Learning Sebagai Alternatif Model Pembelajaran. Lembaran Ilmu Kependidikan, 46(1), 23-27. https://doi.org/10.15294/lik.v46i1.10183

Patria, L., \& Yulianto, K. (2011). Pemanfaatan Facebook Untuk Menunjang Kegiatan Belajar Mengajar Online Secara Mandiri. Seminar Nasional FMIPA-UT 2011. http://repository.ut.ac.id/2305/

Petrovic, N., Petrović, D., Jeremic, V., Milenkovic, N., \& Cirovic, M. (2012). Possible Educational Use of Facebook in Higher Environmental Education.

Pressman, R. S. (2005). Software engineering: A practitioner's approach. Palgrave macmillan.

Robinson, D. E., \& Wizer, D. R. (2016). Universal Design for Learning and the Quality Matters Guidelines for the Design and Implementation of Online Learning Events. International Journal of Technology in Teaching and Learning, 12(1), 17-32.

Simamora, E. (2020). Pelatihan Pengembangan E-Learning untuk Meningkatkan Inovasi Guru dalam Pembelajaran di SMKN 1 Lintongnihuta. Jurnal Teknologi Informasi \& Komunikasi dalam pendidikan, 7(1), 26-36. https://doi.org/10.24114/jtikp.v7i1.22629

Sugiyono, S. (2010). Metode Penelitian Pendidikan Pendekatan Kuantitatif, Kulaitatif dan $R \&$ D. Alfa Beta.

Wijaya, S. W. (2007). Mobile Learning Sebagai Model Pembelajaran Alternatif Bagi Pemulihan Pendidikan Di Daerah Bencana Alam Gempa Bumi Yogyakarta. Jurusan Teknik Informatika, Univ. Sanata Darma. 